\title{
Mathematic Modelling and Optimization of Bank Asset and Liability by Using Fractional Goal Programing Approach
}

\author{
Seyed Mohammad Esmaeil Pourmohammad Azizi, and Abdolsadeh Neisy
}

\begin{abstract}
In economic and finance, function of modelling and optimization is substantial. In fact, by using modelling we can implement, analyze, and control different theories of economic and finance in the market. Bank's asset and liability management is one of the most important areas of study in finance. In this structure, bank's asset and liability portfolio including lending, bonds and received deposit is optimized by expressing objective and constraint regarding different contract positions. In this paper, the application of Operation Research in the structure of modelling and optimization of bank's asset and liability management is so obvious. In fact, it is an instrument to find the highest level of utility. In this research, we start with defining the concept of special finance ratio in bank's balance sheet, then we consider notation for any decision variable. With due attention to these definitions, we wrote ratio in the form of mathematics formula and this is of importance in the body of this paper; and its distinction from other researches is the using of financial ratio for optimization. In the construction of this ratio formulation, some ratio are objectives and others are constraints guiding us to find mathematical programming and then to optimize it. In the construction of this formulation, there are absolute phrases and some objectives with goal, so we have goal fractional multi-objectives problems that in the part of the solving method of the paper, we present a method by change of variables. After solving this problem, we design bank's behavioral policies and/or we can compare the optimized state with what has happened.
\end{abstract}

Index Terms-Modelling and optimization, fractional programming, goal programming, Asset and liability management.

\section{INTRODUCTION}

In every society, the bank is one of the main economic entities. Collecting the funds and allocating them correctly and injecting them to the industries are among of the main jobs in which banks play the important role. Undoubtedly, correctly allocating these financial resources is a substantial principle and a consolidated support for the banks so that they are directed in a way to get rid of any doubt and then be more extensively present in micro- and macro-economy. Banks can be exemplified to a thermometer in society that indicates a number based on the temperature of environment; hence, it is possible to measure the economic situation of the society according to banks' situation. The banks' presence in

Manuscript received December 22, 2016; revised April 1, 2017.

Seyed Mohammad Esmaeil Pourmohammad Azizi is with the graduate of financial mathematics, Department of mathematics, Allameh Tabataba'i University (ATU), Tehran, Iran (e-mail: e.azizi@atu.ac.ir).

Abdolsadeh Neisy is with the faculty of Financial Mathematics, Department of mathematics, Allameh Tabataba'i University (ATU), Tehran, Iran (e-mail: a_neisy@atu.ac.ir). industry is an inevitable fact. If there is an industry facing challenges in liquidity and it is possible to know that this is supported by a bank, it would develop its industry more readily. In contrast, if the banking society was sick, the best situation is that industry would not develop [1]-[4]. Similar to other entities, banks are attempting to maximize the profit and make its customers and stakeholders satisfied. In this regard, asset and liability management is an important instrument. Based on the resources limitation, prevention from asset loss and correctly allocating the assets and liability and minimizing the low-profit structures and unproductive and concentrating on the high-profit classes can be the most important reasons of importance and necessity of the research in this field which aims to control risk and value creating for stakeholders and so on[5]-[9]. Without considering the asset and liability management, banking not only leads to the assets loss, but bank also would distant away from the competitive situation with domestic and foreign banks. One of the necessities in order for banks to be interacting with foreign banks is respecting the Basel committee rules. Among the important rules in Basel is having the asset and liability management committee, planning for respecting the financial ratio and correctly allocating the assets and liability. Asset and liability management in bank differs highly from other entities. For this reason, banks' assets and liability models differ from other entities and organization. For example, consider the positions of stakeholders and depositors. Stakeholders look for profit and revenue increase; hence, they decide to make use of the maximum sources in high-profit structures like loans. On the other hand, what can draw the depositors' attention is the amount of liquidity and banks capability to refund the conditions as such which is not in line with previous case. To make any position satisfied is one of the main duties of the asset and liability management committee. In fact, if one wanted to generally look at this structure, there would be two comprehensive views: maximizing profit and minimizing risk without any relation in between. In banking process, the credits given asset and liability of the received deposits are the most important sections of the revenue. These two factors are divided to short-term or low-price and long-term and high-price and the main goal of the maximizing the profit and minimizing the risk is to make assets and liability aligned. Generally, in profit maximizing approach irrespective of the risk of the asset and liability, one seeks to maximize the profits received. In this structure, cheap sources attraction and allocating it to the high-price facilities in expected in objectives; so, long-term facilities and short-term deposits are more important than short-term facilities and long-term deposits 
and are mostly applied in resource allocation. In contrast, considering the risk irrespective of profit leads use to another structure, concentrating on short-term and low-price liability attraction in vicinity of the liquidity risk causes that we prevent from these liabilities and the long-term liabilities are considered due to the limitations and fine approach. In facilities also the long-term facilities are more important than short-term facilities due to the credit risks. Indeed, these positions are exactly in contradictory directions to each other and the role of asset and liability management would be stabilized [6], [10]-[13]. In the field of liability and assert management analysis, there have been many researches in various areas. Ventura Bravo \& Pereira da Silva (2006), Gulpinar \& Pachamanova (2013), Birge \& Judice (2013), and Kusy \& Ziemba (1986) provided and investigated different techniques of the asset and liability management. Some researches such as Tektas, Nur Ozkan-Gunay, \& Gunay (2005), Das, Lu, Papaioannou \& Petrova (2012) stated the asset and liability management model for critical situations. Also, Claessens \& van Horen (2012) investigated the interdependence between domestic and foreign banks on asset and liability management and its effect on their relations. Important studies in this field which particularly investigated this regard can be mentioned as Romanyuk (2010), Amenc, Martellini, \& Ziemann (2007), Mitra \& Schwaiger (2011), Zenios \& Ziemba (2006), Brick (2012) and Henroid (2007) which investigated the techniques for asset and liability management with risk management goal and correctly allocation of the liabilities and assets using previous data about the asset and liability. In following section, the methodology and explanation of the solutions and instruments used are explained and then, a model is provided and finally, we would calculate the numerical values.

\section{MOdELING}

Nowadays, in developing countries it is a valuable privilege to have relationship with foreign banks and based on banking international law, presence of asset and liability management committee presence is the main part of every bank. This group is also called ALCO. Among the affairs this committee takes into consideration is banks reaching the considered financial ratio or in international level, is respecting the Basel financial ratio. Our research approach in this article if to reach the financial ratio, arrangement and allocate correctly the asset and liability by predicting the reaching a particular level of the asset and liability and taking into account a bound for both asset and liability so that the results obtained would not be deviated from the logical state. The study objective in this section is indeed to find an optimal point of the high amount of asset and liability so that banks would achieve the maximum profit from resources. Generally, optimizing the asset and liability would provide the bank with correct policy making for its future so that, based on the hypotheses considered, minimum cost and highest revenue would be achieved.

\section{A. Methodology}

In order to comprehensively express a mathematical model, we need a signing for variables of the model decision so that we represent the overall mode in mathematical language. The assets are denoted by A and the liability is denoted by L and S would be the positions of the stakeholders. Also, for revenue we use $\mathrm{R}$ and $\mathrm{O}$ for costs and other revenues and lateral costs are denoted by $T$.

Revenues and cost from the assets and liabilities using the interest rate $r$, are as follow:

$$
\begin{array}{lll}
R_{1}=r_{1} * A_{10} & R_{2}=r_{2} * A_{8} & R_{3}=r_{3} * A_{7} \\
R_{4}=r_{4} * A_{4} & R_{5}=r_{5} * A_{6} & R_{6}=r_{6} * A_{11} \\
O_{1}=r^{\prime}{ }_{1} *\left(L_{5}+L_{6}\right) & O_{2}=r^{\prime}{ }_{2} * L_{1} &
\end{array}
$$

Where, $\mathrm{A}_{4}, \mathrm{~A}_{6}, \mathrm{~A}_{7}, \mathrm{~A}_{8}, \mathrm{~A}_{10}$, and $\mathrm{A}_{11}$ are legal deposit, bonds, loan and credits given to banks, loan and credit and other demands, Islamic contracts facilities and partnerships, respectively. Also, $\mathrm{R}_{1}, \mathrm{R}_{2}, \mathrm{R}_{3}, \mathrm{R}_{4}, \mathrm{R}_{5}, \mathrm{R}_{6}$ are in fact Islamic contracts transactions revenue, loan profit and facilities given and other demands, loan profit and credits given to banks, legal deposit profit, bond profit and profit of partnership and investment and the interest rates are $r_{1}, r_{2}, r_{3}, r_{4}, r_{5}, r_{6}$; respectively. $\mathrm{O}_{1}$ and $\mathrm{O}_{2}$ are profits of the deposits and loans with interest rates of $\mathrm{r}_{1}{ }_{1}$ and $\mathrm{r}_{2}{ }_{2}$. With above expression, one can reduce the amount of the calculations and for other cases, we consider the approximate values.

As mentioned earlier, the goal is to teach the financial ratio and in this research, we are trying to achieve this goal and by respecting all cases, we are optimizing the portfolio. Ratio and variables used in this article are financial ratio defined in [14].

\section{1) Objectives}

\section{a) Credit given/received deposits/ratio}

One of the important ratios for banks financial structure is the credit given/received deposits ratio. If this ratio in banks exceeded the society industry index, it is possible that bank face with liquidity challenges and if it was lower than the industry index, indicates the insufficiency of the bank resources for giving loans.

$$
\begin{aligned}
& \text { Credit given/received deposits ration } \\
& \qquad=\frac{\text { loans given }}{\text { deposits received }}
\end{aligned}
$$

One of our goals is to minimize the distance between credits given/deposits received ratio relative to the industry average:

$$
\begin{gathered}
\operatorname{Min} \mid\left(\mathrm{A}^{1}{ }_{7}+\mathrm{A}^{2}{ }_{7}+\mathrm{A}_{8}{ }_{8}+\mathrm{A}_{8}^{2}+\mathrm{A}^{1}{ }_{10}+\mathrm{A}^{2}{ }_{10}+\mathrm{A}_{11}+\mathrm{M}_{1}+\mathrm{M}_{2}\right) /\left(\mathrm{L}_{1}+\right. \\
\left.\mathrm{L}_{5}+\mathrm{L}_{6}\right)-\mathrm{E}\left[\mathrm{G}_{1}{ }_{1}\right] \mid
\end{gathered}
$$

where, M1 and M2 are doubtful reserved of the credits given and other demand and Islamic contract facilities, respectively. $\mathrm{E}\left[\mathrm{G}_{1}{ }_{1}\right]$ is the expectancy of ratio in industry. $\mathrm{L}_{1}, \mathrm{~L}_{5}$ and $\mathrm{L}_{6}$ are customers' current debts and demand deposits, short-term and similar deposits and long-term and similar deposits. In above target function, $A_{7}^{1}, A_{8}^{1}, A_{10}^{1}$ are long-term facilities of assets $A_{7}, A_{8}$ and $A_{10}$ and $A_{7}^{2}, A_{8}^{2}, A_{10}^{2}$ are short-term facilities of assets $A_{7}, A_{8}$ and $A_{10}$ in banks for customers and other banks which is as follow:

$$
\begin{array}{r}
A_{7}=A_{7}^{1}+A^{2}{ }_{7} \quad A_{8}=A_{8}^{1}+A^{2}{ }_{8} \\
A_{10}=A_{10}^{1}+A_{10}^{2}
\end{array}
$$




\section{b) Leverage ratios}

The sum of liabilities to the stakeholders' equity is called leverage ratio. In fact, pervasiveness of the liability is stated by the stakeholders' equity. If it exceeded this ratio, it means the risk of depositing in asset and liability structure and if it was lower than this ratio, it means the blockage of the stakeholders' share and lack of efficiency of the bank in receiving deposits. The level of this ratio is measured with market competitors.

$$
\text { levelrage ratio }=\frac{\text { sum of liabilities }}{\text { sum of stakeholders } \text { equity }^{\text {sum }}}
$$

Therefore, we are trying to minimize the difference between leverage ratio and average of the society:

$$
\operatorname{Min}\left|\left(\sum_{i=1}^{11} L_{\mathrm{i}} / \sum_{i=1}^{4} S_{\mathrm{i}}\right)-\mathrm{E}\left[\mathrm{G}_{2}^{\prime}\right]\right|
$$

$\mathrm{E}\left[\mathrm{G}_{2}\right]$ is the expectancy of the leverage ratio in industry. In above ratio, $\mathrm{L}_{2}$ is the central account and $\mathrm{L}_{3}$ is the domestic banks balance after the exchange, $\mathrm{L}_{4}$ is the foreign bank balance after the exchange, $\mathrm{L}_{7}$ is the governmental accounts, $\mathrm{L}_{8}$ is the central bank, $\mathrm{L}_{9}$ is capital reserve, $\mathrm{L}_{10}$ is deferred exchange debts, $\mathrm{L}_{11}$ is other debts, $\mathrm{S}_{1}$ is the capital, $\mathrm{A}_{2}$ is legal deposit and $S_{3}$ and $S_{4}$ are other deposits and profit or loss accumulated in balance sheet, respectively.

c) Return on average profitable assets

Among the important ratio in bank financial statements is return on average profitable assets. This ratio is calculated by dividing the operational income by the average profitable assets. This ratio concentrates on the quality of the credits given.

return on average profitable assets

$$
=\frac{\text { sum of operational income }}{\text { avrage profitable assets }}
$$

Achieving the industrial average profitable assets can be as follow:

$\operatorname{Min} \mid\left(\left(\sum_{i=1}^{6} R_{\mathrm{i}}-\mathrm{R}_{4}\right) /\left(\left(\left(\mathrm{A}_{6}+\mathrm{A}_{11}+\mathrm{A}^{1}{ }_{7}+\mathrm{A}^{2}{ }_{7}+\mathrm{A}^{1}{ }_{8}+\mathrm{A}^{2}{ }_{8}+\mathrm{A}^{1}{ }_{10}+\right.\right.\right.\right.$ $\left.\left.\left.\left.\mathrm{A}^{2}{ }_{10}\right)^{\mathrm{L}}+\left(\mathrm{A}_{6}+\mathrm{A}_{11}+\mathrm{A}^{1}{ }_{7}+\mathrm{A}^{2}{ }_{7}+\mathrm{A}_{8}{ }_{8}+\mathrm{A}^{2}{ }_{8}+\mathrm{A}^{1}{ }_{10}+\mathrm{A}^{2}{ }_{10}\right)^{\mathrm{N}}\right) / 2\right)\right)-$ $\mathrm{E}\left[\mathrm{G}_{3}\right]$

$\mathrm{E}\left[\mathrm{G}_{3}{ }_{3}\right]$ is the prediction of average profitable assets in industry. Of course, in order to minimize the calculations and based on equation 1 above expression can be considered as:

$$
\begin{aligned}
& \operatorname{Min} \mid\left(\left(\mathrm{r}_{1} * \mathrm{~A}_{10}+\mathrm{r}_{2} * \mathrm{~A}_{8}+\mathrm{r}_{3} * \mathrm{~A}_{7}+\mathrm{r}_{5} * \mathrm{~A}_{6}+\mathrm{r}_{6} * \mathrm{~A}_{11}\right) /\left(\left(\left(\mathrm{A}_{6}+\mathrm{A}_{11}+\right.\right.\right.\right. \\
& \left.\mathrm{A}^{1}{ }_{7}+\mathrm{A}^{2}{ }_{7}+\mathrm{A}_{8}{ }_{8}+\mathrm{A}^{2}{ }_{8}+\mathrm{A}^{1}{ }_{10}+\mathrm{A}^{2}{ }_{10}+\right)^{\mathrm{L}}+\left(\mathrm{A}_{6}+\mathrm{A}_{11}+\mathrm{A}^{1}{ }_{7}+\mathrm{A}^{2}{ }_{7}+\mathrm{A}^{1}{ }_{8}+\right. \\
& \left.\left.\left.\left.\mathrm{A}^{2}{ }_{8}+\mathrm{A}^{1}{ }_{10}+\mathrm{A}^{2}{ }_{10}\right)^{\mathrm{N}}\right) / 2\right)\right)-\mathrm{E}\left[\mathrm{G}_{3}{ }_{3}\right] \mid
\end{aligned}
$$

\section{d) Interest rate paid on deposits}

The position in contrast to the average profitable asset is the interest rate paid on deposit. This ratio is the dividing the operational costs by average deposits.

$$
\text { interest rate paid on deposits }=\frac{\text { sum of profit cosy }}{\text { avrage deposits }}
$$

Then naturally, we are trying to minimize the interest rate paid on the deposits, of course the customers' satisfaction also is considered:

$$
\operatorname{Min}\left(\left(\mathrm{O}_{1}+\mathrm{O}_{2}\right) /\left(\left(\left(\mathrm{L}_{1}+\mathrm{L}_{5}+\mathrm{L}_{6}\right)^{\mathrm{L}}+\left(\mathrm{L}_{1}+\mathrm{L}_{5}+\mathrm{L}_{6}\right)^{\mathrm{N}}\right) / 2\right)\right) \text {. }
$$

Then, from equation 1 we have:

$$
\begin{aligned}
& \operatorname{Min}\left(\left(\mathrm{r}_{1}{ }_{1} *\left(\mathrm{~L}_{5}+\mathrm{L}_{6}\right)+\mathrm{r}^{\prime}{ }_{2} * \mathrm{~L}_{1}\right) /\left(\left(\left(\mathrm{L}_{1}+\mathrm{L}_{5}+\mathrm{L}_{6}\right)^{\mathrm{L}}+\left(\mathrm{L}_{1}+\mathrm{L}_{5}+\right.\right.\right.\right. \\
& \left.\left.\left.\left.\mathrm{L}_{6}\right)^{\mathrm{N}}\right) / 2\right)\right)
\end{aligned}
$$

\section{e) Net profit/average profitable assets ratio}

This ratio is used for evaluating the asset and liability management state. High increase in this ratio in comparison with other banks means the relevance of the bank management. While, minimum of this ratio have to be stable with a lower bound so that it can compete with other banks. If this ratio was low, it means that bank paid credits with lower ratio to other banks or it as large human force or outstanding demands. In contrast, high amount with stable state means high rate of credit paying or similar cases.

$$
\begin{gathered}
\text { net profit/ average profitable assets }= \\
\frac{\text { net profit }}{\text { average profitable assets }}
\end{gathered}
$$

We are trying to maximize this ratio:

$$
\begin{gathered}
\operatorname{Max}\left(\sum_{i=1}^{6} R_{\mathrm{i}}-\mathrm{O}_{1}-\mathrm{O}_{2}+\left(\mathrm{T}_{1}+\mathrm{T}_{2}+\mathrm{T}_{3}+\mathrm{T}_{4}+\mathrm{T}_{5}+\mathrm{T}_{6}+\mathrm{T}_{7}+\mathrm{T}_{8}+\right.\right. \\
\left.\left.\mathrm{T}_{9}\right)\right) /\left(\left(\left(\mathrm{A}_{6}+\mathrm{A}_{11}+\mathrm{A}^{1}{ }_{7}+\mathrm{A}^{2}{ }_{7}+\mathrm{A}^{1}{ }_{8}+\mathrm{A}^{2}{ }_{8}+\mathrm{A}^{1}{ }_{10}+\mathrm{A}^{2}{ }_{10}\right)^{\mathrm{L}}+\left(\mathrm{A}_{6}+\mathrm{A}_{11}+\right.\right.\right. \\
\left.\left.\left.\left.\mathrm{A}^{1}{ }_{7}+\mathrm{A}^{2}{ }_{7}+\mathrm{A}^{1}{ }_{8}+\mathrm{A}^{2}{ }_{8}+\mathrm{A}^{1}{ }_{10}+\mathrm{A}^{2}{ }_{10}\right)^{\mathrm{N}}\right) / 2\right)\right) .
\end{gathered}
$$

From equation 1 we have:

$$
\begin{gathered}
\operatorname{Max}\left(\mathrm{r}_{1} * \mathrm{~A}_{10}+\mathrm{r}_{2} * \mathrm{~A}_{8}+\mathrm{r}_{3} * \mathrm{~A}_{7}+\mathrm{r}_{4} * \mathrm{~A}_{4}+\mathrm{r}_{5} * \mathrm{~A}_{6}+\mathrm{r}_{6} * \mathrm{~A}_{11}-\right. \\
\mathrm{r}_{1}{ }_{1} *\left(\mathrm{~L}_{5}+\mathrm{L}_{6}\right)-\mathrm{r}_{2}{ }_{2} \mathrm{~L}_{1}+\left(\mathrm{T}_{1}+\mathrm{T}_{2}+\mathrm{T}_{3}+\mathrm{T}_{4}+\mathrm{T}_{5}+\mathrm{T}_{6}+\mathrm{T}_{7}+\mathrm{T}_{8}+\right. \\
\left.\left.\mathrm{T}_{9}\right)\right) /\left(\left(\left(\mathrm{A}_{6}+\mathrm{A}_{11}+\mathrm{A}^{1}{ }_{7}+\mathrm{A}^{2}{ }_{7}+\mathrm{A}^{1}{ }_{8}+\mathrm{A}^{2}{ }_{8}+\mathrm{A}^{1}{ }_{10}+\mathrm{A}^{2}{ }_{10}\right)^{\mathrm{L}}+\left(\mathrm{A}_{6}+\mathrm{A}_{11}+\right.\right.\right. \\
\mathrm{A}^{1}{ }_{7}+\mathrm{A}^{2}{ }_{7}+\mathrm{A}^{1}{ }_{8}+\mathrm{A}^{2}{ }_{8}+\mathrm{A}^{1}{ }_{10} \\
\left.\left.\left.\left.\mathrm{~A}^{2}{ }_{10}\right)^{\mathrm{N}}\right) / 2\right)\right) .
\end{gathered}
$$

where, $T_{1}, T_{2}, T_{3}, T_{4}, T_{5}, T_{6}, T_{7}, T_{8}$ and $T_{9}$ are other costs and lateral income such as received fees, other incomes, doubtful demands costs, cost of investment and partnership reduction, personnel costs, general and administrative costs, equipment and properties depreciation costs, net transaction and currency exchanges and paid fees.

\section{f) Net profit/average stakeholders' equity ratio}

If this ratio was high like ratio of net profit to average profitable assets, it would be beneficial for banks and can state the relevance of the bank's asset and liability management:

$$
\begin{aligned}
& \text { ratio of net profit to average stakeholders'equity }= \\
& \qquad \frac{\text { net profit }}{\text { average stakeholders'equity }}
\end{aligned}
$$

The goal we are trying to achieve is to maximize this ratio:

$$
\begin{gathered}
\operatorname{Max}\left(\sum_{i=1}^{6} R_{\mathrm{i}}-\mathrm{O}_{1}-\mathrm{O}_{2}+\left(\mathrm{T}_{1}+\mathrm{T}_{2}-\mathrm{T}_{3}-\mathrm{T}_{4}-\mathrm{T}_{5}-\mathrm{T}_{6}-\mathrm{T}_{7}+\mathrm{T}_{8}+\right.\right. \\
\left.\left.\mathrm{T}_{9}\right)\right) /\left(\left(\left(\sum_{i=1}^{4} S_{\mathrm{i}}\right)^{\mathrm{L}}+\left(\sum_{i=1}^{4} S_{\mathrm{i}}\right)^{\mathrm{N}}\right) / 2\right)
\end{gathered}
$$

From equation 1 we have: 
$\operatorname{Max}\left(\mathrm{r}_{1} * \mathrm{~A}_{10}+\mathrm{r}_{2} * \mathrm{~A}_{8}+\mathrm{r}_{3} * \mathrm{~A}_{7}+\mathrm{r}_{4} * \mathrm{~A}_{4}+\mathrm{r}_{5} * \mathrm{~A}_{6}+\mathrm{r}_{6} * \mathrm{~A}_{11}-\right.$ $\left.\mathrm{r}^{\prime}{ }_{1} *\left(\mathrm{~L}_{5}+\mathrm{L}_{6}\right)-\mathrm{r}_{2}{ }_{2} * \mathrm{~L}_{1}+\left(\mathrm{T}_{1}+\mathrm{T}_{2}-\mathrm{T}_{3}-\mathrm{T}_{4}-\mathrm{T}_{5}-\mathrm{T}_{6}-\mathrm{T}_{7}+\mathrm{T}_{8}+\mathrm{T}_{9}\right)\right) /$ $\left(\left(\left(\sum_{i=1}^{4} S_{\mathrm{i}}\right)^{\mathrm{L}}+\left(\sum_{i=1}^{4} S_{\mathrm{i}}\right)^{\mathrm{N}}\right) / 2\right)$

\section{g) Other goals}

Other goals and limitations of this study are as follow:

Achieving the asset and liability to the predicted particular amount:

$$
\begin{array}{r}
\operatorname{Min}\left|\sum_{i=1}^{15} A \sum_{i=1}^{18} A_{\mathrm{i}}-\mathrm{A}^{\mathrm{N}}\right| \\
\operatorname{Min}\left|\sum_{i=1}^{11} L_{\mathrm{i}}-\mathrm{L}^{\mathrm{N}}\right|
\end{array}
$$

where $L^{N,} A^{N}$ are amount of the asset and liability, respectively and $A_{1}$ is the banknotes and coins, $A_{2}$ is the domestic banks balance after exchange and $A_{3}$ is the foreign banks balance after exchange, $\mathrm{A}_{5}, \mathrm{~A}_{9}, \mathrm{~A}_{12}, \mathrm{~A}_{13}, \mathrm{~A}_{14}$ and $\mathrm{A}_{15}$ are other deposits, the result of moderation due to the currency rate alignment, submitted collaterals, other assets, government, equipment and properties, respectively.

Profit maximization:

$$
\operatorname{Max}\left(\sum_{i=1}^{6} R_{\mathrm{i}}-O_{1}-\mathrm{O}_{2}+\left(\mathrm{T}_{1}+\mathrm{T}_{2}+\mathrm{T}_{3}+\mathrm{T}_{4}+\mathrm{T}_{5}+\mathrm{T}_{6}+\mathrm{T}_{7}+\mathrm{T}_{8}+\mathrm{T}_{9}\right)\right) .
$$

Using equation 1 , we have:

$$
\operatorname{Max}\left(\mathrm{r}_{1} * \mathrm{~A}_{10}+\mathrm{r}_{2} * \mathrm{~A}_{8}+\mathrm{r}_{3} * \mathrm{~A}_{7}+\mathrm{r}_{4} * \mathrm{~A}_{4}+\mathrm{r}_{5} * \mathrm{~A}_{6}+\mathrm{r}_{6} * \mathrm{~A}_{11}-\right.
$$

$\left.\left(\mathrm{L}_{5}+\mathrm{L}_{6}\right)-\mathrm{r}_{2}{ }^{*} \mathrm{~L}_{1}+\left(\mathrm{T}_{1}+\mathrm{T}_{2}+\mathrm{T}_{3}+\mathrm{T}_{4}+\mathrm{T}_{5}+\mathrm{T}_{6}+\mathrm{T}_{7}+\mathrm{T}_{8}+\mathrm{T}_{9}\right)\right)$.

Received deposits maximization:

$$
\operatorname{Max}\left(\mathrm{L}_{1}+\mathrm{L}_{5}+\mathrm{L}_{6}\right) \text {. }
$$

Facilities and deposits model based on the bank risk-taking level:

$$
\begin{gathered}
\operatorname{Max}(1-\gamma)\left[\mathrm{A}^{1}{ }_{7}+\mathrm{A}^{1}{ }_{8}+\mathrm{A}^{1}{ }_{10}+\mathrm{L}_{1}+\mathrm{L}_{5}\right] \\
\operatorname{Ma} \gamma\left[\mathrm{A}^{2}{ }_{7}+\mathrm{A}^{2}{ }_{8}+\mathrm{A}^{2}{ }_{10}+\mathrm{L}_{6}\right]
\end{gathered}
$$

$\gamma$ is the bank risk-taking coefficient.

\section{2) Limitations}

a) Deposits growth

The most important bank's financial securing resource is the deposit growth; hence the growth of deposits has to be more than the inflation.

\section{deposits growth $=\frac{\Theta}{\omega}$}

That $\Theta$ is deposit amount at the end of period minus deposit amount at the beginning of period and $\omega$ is deposit amount at the beginning of period

Based on above mentioned issues, the deposits growth would be as:

$$
\begin{gathered}
\left(\left(\mathrm{L}_{1}-\mathrm{L}_{1}{ }_{1}\right) / \mathrm{L}_{1}{ }_{1}\right)>\text { Inflation } \\
\left(\left(\mathrm{L}_{5}-\mathrm{L}_{5} \mathrm{~L}_{5} / \mathrm{L}_{5}\right)>\right.\text { Inflation } \\
\left(\left(\mathrm{L}_{6}-\mathrm{L}_{6}{ }_{6}\right) / \mathrm{L}_{6}\right)>\text { Inflation } \\
L_{1}^{L}, L_{5}^{L}, L_{6}^{L} \text { are previous period debts. }
\end{gathered}
$$

\section{3) Doubtful reserved}

These reserves are the main pillar of the banks' assets and liability management structure and codifying it is conducted using the previous and future predicted data.

$$
\begin{gathered}
\text { doubtful reserves }= \\
\frac{\text { sum of the doubful demand reserves }}{\text { gross facilities granted }}
\end{gathered}
$$

Taking this factor into consideration in the model is as:

$$
\mathrm{M}_{1}+\mathrm{M}_{2} \geq \mathrm{Z} * \mathrm{n}
$$

$\mathrm{Z}$ Is the lost capital and $\mathrm{n}$ is its period.

\section{a) Capital sufficiency ratio}

This ratio is calculated by dividing the stakeholders' equity by the risky assets which considers a risk taking coefficient for each asset. In what follows, the coefficient of assets is stated. Assets without coefficient are of zero coefficients.

$$
\begin{aligned}
& \text { capital sufficiency ratio }= \\
& \frac{\text { sum of stakeholders'equity }}{\text { sum of risky assets }}
\end{aligned}
$$

Respecting this ratio is also one of the limitations of our model:

$$
\begin{aligned}
& \left(\sum_{i=1}^{4} S_{\mathrm{i}} /\left(\mathrm{A}_{2} \alpha_{1}+\mathrm{A}_{3} \alpha_{2}+\mathrm{A}_{5} \alpha_{3}+\mathrm{A}_{6} \alpha_{4}+\left(\mathrm{A}_{7}^{1}+\mathrm{A}^{2}{ }_{7}\right)\right.\right. \\
& \alpha_{5}+\mathrm{A}_{11} \alpha_{6}+\left(\mathrm{A}_{8}^{1}+\mathrm{A}_{8}^{2}\right) \alpha_{7}+\mathrm{A}_{9} \alpha_{8}+\left(\mathrm{A}_{10}^{1}+\mathrm{A}^{2}{ }_{10}\right) \alpha_{9}+\mathrm{A}_{12} \alpha_{10}+\mathrm{A}_{13} \\
& \alpha_{11}+\mathrm{A}_{14} \alpha_{12}+\mathrm{A}_{15} \alpha_{13}+\mathrm{C}_{1} \alpha_{14}+ \\
& \left.\left.\mathrm{C}_{2} \alpha_{15}\right)\right)>0.08 \text {. }
\end{aligned}
$$

where, $\alpha_{1}, \alpha_{2}, \alpha_{3}, \alpha_{4}, \alpha_{5}, \alpha_{6}, \alpha_{7}, \alpha_{8}, \alpha_{9}, \alpha_{10}, \alpha_{11}$ , $\alpha_{12}, \alpha_{13}, \alpha_{14}, \alpha_{15}$ are capital sufficiency ratio percent as $20 \%, 20 \%, 20 \%, 10 \%, 50 \%, 100 \%, 100 \%, 100 \%, 100 \%$, $100 \%, 100 \%, 100 \&, 50 \%$ and $100 \%$, respectively.

\section{b) Capital/asset ratio}

In fact, this ratio is a type of ensuring that bank can pay its debts in critical situation to the certain extent. If it was low excessively, the bank economy would face challenge in critical economic conditions. This ratio varies between countries which is $7 \%$ in USA.

$$
\text { capital to asset ratio }=\frac{\text { sum of stock equity }}{\text { sum of assets }}
$$

Among the limitation we faced with is minimum ratio of capital to asset equal to the average of industry:

$$
\mathrm{S}_{1} /\left(\sum_{\mathrm{i}=1}^{18} \mathrm{~A}_{\mathrm{i}}\right) \geq \mathrm{E}\left[\mathrm{G}_{4}\right]
$$

$\mathrm{E}\left[\mathrm{G}_{4}{ }_{4}\right]$ is the average ratio in industry.

\section{B. Proposed Model}

Based on modeling and structure statement we explained for goals and limitation, one can obtain the plan structure and optimal value by solving the model 24 as follow:

$$
\begin{aligned}
& \operatorname{Min}\left|\sum_{i=1}^{15} A_{\mathrm{i}}-\mathrm{A}^{\mathrm{N}}\right| \\
& \operatorname{Min}\left|\sum_{i=1}^{11} L_{\mathrm{i}}-\mathrm{L}^{\mathrm{N}}\right|
\end{aligned}
$$


$\operatorname{Min} \mid\left(\mathrm{A}^{1}{ }_{7}+\mathrm{A}^{2}{ }_{7}+\mathrm{A}^{1}{ }_{8}+\mathrm{A}^{2}{ }_{8}+\mathrm{A}^{1}{ }_{10}+\mathrm{A}^{2}{ }_{10}+\mathrm{A}_{11}+\mathrm{M}_{1}+\mathrm{M}_{2}\right) /($

$\left.\mathrm{L}_{1}+\mathrm{L}_{5}+\mathrm{L}_{6}\right)-\mathrm{E}\left[\mathrm{G}_{1}{ }_{1}\right]$

$\operatorname{Min}\left|\left(\sum_{i=1}^{11} L_{\mathrm{i}} / \sum_{i=1}^{4} S_{\mathrm{i}}\right)-\mathrm{E}\left[\mathrm{G}_{2}^{\prime}\right]\right|$

Min $\mid\left(\left(\mathrm{r}_{1} * \mathrm{~A}_{10}+\mathrm{r}_{2} * \mathrm{~A}_{8}+\mathrm{r}_{3} * \mathrm{~A}_{7}+\mathrm{r}_{5} * \mathrm{~A}_{6}+\mathrm{r}_{6} * \mathrm{~A}_{11}\right) /\left(\left(\left(\mathrm{A}_{6}+\mathrm{A}_{11}+\right.\right.\right.\right.$ $\left.\mathrm{A}^{1}{ }_{7}+\mathrm{A}^{2}{ }_{7}+\mathrm{A}_{8}^{1}{ }_{8}+\mathrm{A}_{8}{ }_{8}+\mathrm{A}^{1}{ }_{10}+\mathrm{A}^{2}{ }_{10}\right)^{\mathrm{L}}+\left(\mathrm{A}_{6}+\mathrm{A}_{11}+\mathrm{A}^{1}{ }_{7}+\mathrm{A}^{2}{ }_{7}+\mathrm{A}^{1}{ }_{8}+\right.$ $\left.\left.\left.\left.\mathrm{A}^{2}{ }_{8}+\mathrm{A}^{1}{ }_{10}+\mathrm{A}^{2}{ }_{10}\right)^{\mathrm{N}}\right) / 2\right)\right)-\mathrm{E}\left[\mathrm{G}^{\prime}{ }_{3}\right]$

$\operatorname{Max}\left(\mathrm{r}_{1} * \mathrm{~A}_{10}+\mathrm{r}_{2} * \mathrm{~A}_{8}+\mathrm{r}_{3} * \mathrm{~A}_{7}+\mathrm{r}_{4} * \mathrm{~A}_{4}+\mathrm{r}_{5} * \mathrm{~A}_{6}+\mathrm{r}_{6} * \mathrm{~A}_{11}-\right.$ $\left.\mathrm{r}_{1}^{\prime} *\left(\mathrm{~L}_{5}+\mathrm{L}_{6}\right) \quad-\mathrm{r}_{2}{ }_{2} * \mathrm{~L}_{1}+\left(\mathrm{T}_{1}+\mathrm{T}_{2}+\mathrm{T}_{3}+\mathrm{T}_{4}+\mathrm{T}_{5}+\mathrm{T}_{6}+\mathrm{T}_{7}+\mathrm{T}_{8}+\mathrm{T}_{9}\right)\right) /$ $\left(\left(\left(\mathrm{A}_{6}+\mathrm{A}_{11}+\mathrm{A}^{1}{ }_{7}+\mathrm{A}^{2}{ }_{7}+\mathrm{A}_{8}{ }_{8}+\mathrm{A}^{2}{ }_{8}+\mathrm{A}^{1}{ }_{10}+\mathrm{A}^{2}{ }_{10}\right)^{\mathrm{L}}+\left(\mathrm{A}_{6}+\mathrm{A}_{11}+\mathrm{A}^{1}{ }_{7}+\right.\right.\right.$ $\left.\left.\left.\left.\mathrm{A}^{2}{ }_{7}+\mathrm{A}_{8}^{1}{ }_{8}+\mathrm{A}^{2}{ }_{8}+\mathrm{A}^{1}{ }_{10}+\mathrm{A}^{2}{ }_{10}\right)^{\mathrm{N}}\right) / 2\right)\right)$

$\operatorname{Max}\left(r_{1} * A_{10}+r_{2} * A_{8}+r_{3} * A_{7}+r_{4} * A_{4}+r_{5} * A_{6}+r_{6} * A_{11}-\right.$

$\left.\mathrm{r}^{\prime}{ }_{1} *\left(\mathrm{~L}_{5}+\mathrm{L}_{6}\right)-\mathrm{r}_{2}{ }^{*} \mathrm{~L}_{1}+\left(\mathrm{T}_{1}+\mathrm{T}_{2}+\mathrm{T}_{3}+\mathrm{T}_{4}+\mathrm{T}_{5}+\mathrm{T}_{6}+\mathrm{T}_{7}+\mathrm{T}_{8}+\mathrm{T}_{9}\right)\right) /$ $\left(\left(\left(\sum_{i=1}^{4} S_{\mathrm{i}}\right)^{\mathrm{L}}+\left(\sum_{i=1}^{4} S_{\mathrm{i}}\right)^{\mathrm{N}}\right) / 2\right)$

$\operatorname{Min}\left(\left(\mathrm{r}_{1}{ }^{*} *\left(\mathrm{~L}_{5}+\mathrm{L}_{6}\right)+\right.\right.$

$\left.\left.\left.\mathrm{L}_{1}+\mathrm{L}_{5}+\mathrm{L}_{6}\right)^{\mathrm{N}}\right) / 2\right)$ )

$\operatorname{Max}\left(\mathrm{r}_{1} * \mathrm{~A}_{10}+\mathrm{r}_{2} * \mathrm{~A}_{8}+\mathrm{r}_{3} * \mathrm{~A}_{7}+\mathrm{r}_{4} * \mathrm{~A}_{4}+\mathrm{r}_{5} * \mathrm{~A}_{6}+\mathrm{r}_{6} * \mathrm{~A}_{11}-\right.$

$\left.\mathrm{r}_{1}{ }_{1}^{*}\left(\mathrm{~L}_{5}+\mathrm{L}_{6}\right)-\mathrm{r}_{2}{ }_{2} \mathrm{~L}_{1}+\left(\mathrm{T}_{1}+\mathrm{T}_{2}-\mathrm{T}_{3}+\mathrm{T}_{4}+\mathrm{T}_{5}+\mathrm{T}_{6}+\mathrm{T}_{7}+\mathrm{T}_{8}+\mathrm{T}_{9}\right)\right)$

$\operatorname{Max}\left(\mathrm{L}_{1}+\mathrm{L}_{5}+\mathrm{L}_{6}\right)$

$\operatorname{Max}(1-\gamma)\left[\mathrm{A}^{1}{ }_{7}+\mathrm{A}^{1}{ }_{8}+\mathrm{A}^{1}{ }_{10}+\mathrm{L}_{1}+\mathrm{L}_{5}\right]$

$\operatorname{Max} \gamma\left[\mathrm{A}^{2}{ }_{7}+\mathrm{A}^{2}{ }_{8}+\mathrm{A}^{2}{ }_{10}+\mathrm{L}_{6}\right]$

S.t.

$\mathrm{S}_{1} /\left(\sum_{i=1}^{15} A_{\mathrm{i}}\right) \geq \mathrm{E}\left[\mathrm{G}_{4}{ }_{4}\right]$

$\left(\sum_{i=1}^{4} S_{\mathrm{i}} /\left(\mathrm{A}_{2} \alpha_{1}+\mathrm{A}_{3} \alpha_{2}+\mathrm{A}_{5} \alpha_{3}+\mathrm{A}_{6} \alpha_{4}+\left(\mathrm{A}_{7}+\mathrm{A}^{2}{ }_{7}\right) \alpha_{5}+\mathrm{A}_{13}\right.\right.$ $\alpha_{6}+\left(\mathrm{A}_{8}^{1}+\mathrm{A}_{8}^{2} \quad\right) \alpha_{7}+\mathrm{A}_{9} \quad \alpha_{8}+\left(\mathrm{A}_{10}^{1}+\mathrm{A}^{2}{ }_{10}\right) \quad \alpha_{9}+\mathrm{A}_{12} \quad \alpha_{10}+\mathrm{A}_{14}$ $\left.\left.\alpha_{11}+\mathrm{A}_{15} \alpha_{12}+\mathrm{C}_{1} \alpha_{13}+\mathrm{C}_{2} \alpha_{14}\right)\right)>0.08$

$\mathrm{M}_{1}+\mathrm{M}_{2} \geq \mathrm{Z} * \mathrm{n}$

$\left(\left(\mathrm{L}_{1}-\mathrm{L}_{1}\right) / \mathrm{L}_{1}^{\mathrm{L}}\right)>$ Inflation

$\left(\left(\mathrm{L}_{5}-\mathrm{L}_{5}{ }^{\mathrm{L}}\right) / \mathrm{L}_{5}^{\mathrm{L}}\right)>$ Inflation

$\left(\left(\mathrm{L}_{6}-\mathrm{L}_{6}^{\mathrm{L}}\right) / \mathrm{L}_{6}^{\mathrm{L}}\right)>$ Inflation

$$
\mathrm{A} \geq \partial 1 L \geq \partial 2 S \geq \partial 3
$$

\section{Solution}

In above programming structure, the model has several Goals, multiple purposes, fractional and absolute value. We will solve it using the present methods. It is necessary to note that due to frequent studies on this issue, the solutions are not similar; therefore, we explain a simple solution.

\section{1) Goal programing}

Goal programing model is an operation research which seeks to find a particular objective as an applicable one in different fields. In following, we investigate this model [15].

Consider the following simple programing:

$\operatorname{Max}(\operatorname{Min}) f_{i}(x) \quad i=1,2, \ldots, n-1, n$

s.t.

$$
\operatorname{Ax}\left(\begin{array}{l}
\geq \\
= \\
\leq
\end{array}\right) \mathrm{b}
$$

$\mathrm{x} \geq 0$

Goal model with ideal $\mathrm{G}$ is as:

$$
\begin{array}{cc}
\operatorname{Min~}_{1} d_{i}^{+}+w_{2} d_{i}^{-} & i=1,2, \ldots, n-1, n \\
f(x)-G=d_{i}^{+}-d_{i}^{-} & i=1,2, \ldots, n-1, n \\
& \text { s.t. }
\end{array}
$$

$$
\begin{gathered}
\operatorname{Ax}\left(\begin{array}{c}
\geq \\
= \\
\leq
\end{array}\right) \mathrm{b} \\
\mathrm{x}, \mathrm{d}_{\mathrm{i}}^{+}-\mathrm{d}_{\mathrm{i}} \geq 0
\end{gathered}
$$

To solve this model, there are many solutions. Here, we use WGP for solution.

\section{2) Fractional programing}

The other particular situation of optimization models is the Fractional programing whose solution is linearizing which is stated as follow [16]-[18].

Consider the following model:

$$
\begin{gathered}
\operatorname{Max}\left(\text { Min) } \frac{c x+d}{g x+h} \quad\right. \text { s.t. } \\
\operatorname{Ax}\left(\begin{array}{l}
\geq \\
= \\
\leq
\end{array}\right) \mathrm{b} \\
g x+h>0 \\
\mathrm{x} \geq 0
\end{gathered}
$$

In fact, above model can be rewritten as:

$$
\begin{aligned}
& \operatorname{Max}(\operatorname{Min}) \text { cy+dt s.t. } \\
& \operatorname{Ay}\left(\begin{array}{l}
\geq \\
= \\
\leq
\end{array}\right) b t \\
& \text { gy+ht }=1 \\
& y, t \geq 0
\end{aligned}
$$

\section{3) Absolute value}

After linearizing the model due to absolute value, the following approach is used for extraction of the absolute value:

$\operatorname{Min}|f(x)|$

Defining $\mathrm{Z}$ as $\mathrm{Z} \leq|\mathrm{f}(\mathrm{x})|$, above target function is equivalent to:

Min Z s.t.

$$
\begin{gathered}
Z \geq-(f(x)) \\
Z \leq(f(x))
\end{gathered}
$$

After using above methods, a simple programing model is obtained for optimization. It is necessary to note that by linearizing above model, one can solve it using LINGO. Based on model provided, in next section we have numerical results.

\section{NUMERICAL RESULTS}

In this section, we demonstrate a hypothesized bank's previous year information and them we will calculate the optimal state of the assets and liabilities using the previous year information. Then, it will be compared to what happened before. In this section, we considered some estimates for the industry future condition.

The last year information about asset and liability: 


\begin{tabular}{cccc} 
TABLE I: THE ASSET AND LIABILITY OF BANK X IN PRECIOUS YEAR \\
\hline \hline Variable & $\begin{array}{c}\text { Value in previous } \\
\text { year }\end{array}$ & variable & $\begin{array}{c}\text { Value in } \\
\text { previous } \\
\text { year }\end{array}$ \\
\hline $\mathrm{L}_{1}$ & 3018292 & $\mathrm{a}_{1}$ & 32044 \\
$\mathrm{~L}_{2}$ & 470142 & $\mathrm{a}_{2}$ & 54746 \\
$\mathrm{~L}_{3}$ & 2606 & $\mathrm{a}_{3}$ & 964420 \\
$\mathrm{~L}_{4}$ & 293360 & $\mathrm{a}_{4}$ & 2059462 \\
$\mathrm{~L}_{5}$ & 3198672 & $\mathrm{a}_{5}$ & - \\
$\mathrm{L}_{6}$ & 4781164 & $\mathrm{a}_{6}$ & 677540 \\
$\mathrm{~L}_{7}$ & 57786 & $\mathrm{a}_{7}$ & 920316 \\
$\mathrm{~L}_{8}$ & 472334 & $\mathrm{a}_{8}$ & 1873372 \\
$\mathrm{~L}_{9}$ & 26396 & $\mathrm{a}_{9}$ & 3067398 \\
$\mathrm{~L}_{10}$ & 9047612 & $\mathrm{a}_{10}$ & 4113864 \\
$\mathrm{~L}_{11}$ & 718646 & $\mathrm{a}_{11}$ & 779428 \\
$\mathrm{~S}_{1}$ & 1695635 & $\mathrm{a}_{12}$ & 4464 \\
$\mathrm{~S}_{2}$ & 7406 & $\mathrm{a}_{13}$ & 7512270 \\
$\mathrm{~S}_{3}$ & 1820 & $\mathrm{a}_{14}$ & 22008 \\
$\mathrm{~S}_{4}$ & 20036 & $\mathrm{a}_{15}$ & 1965740 \\
& & $\mathrm{c} 1$ & 4309240 \\
& & $\mathrm{c} 2$ & 4569822 \\
\hline \hline
\end{tabular}

In following, information of profit and loss is considered:

\begin{tabular}{cc} 
TABLE II: LOSS AND PROFIT OF BANK X IN PREVIOUS YEAR \\
\hline \hline Variable & Value in previous year \\
\hline $\mathrm{R}_{1}$ & 371482 \\
$\mathrm{R}_{2}$ & 241036 \\
$\mathrm{R}_{3}$ & 24576 \\
$\mathrm{R}_{4}$ & 17050 \\
$\mathrm{R}_{5}$ & 20132 \\
$\mathrm{R}_{6}$ & 492 \\
$\mathrm{O}_{1}$ & 474172 \\
$\mathrm{O}_{2}$ & 26548 \\
$\mathrm{~T}_{1}$ & 107974 \\
$\mathrm{~T}_{2}$ & 19910 \\
$\mathrm{~T}_{3}$ & -49076 \\
$\mathrm{~T}_{4}$ & - \\
$\mathrm{T}_{5}$ & -123986 \\
$\mathrm{~T}_{6}$ & -41050 \\
$\mathrm{~T}_{7}$ & 37580 \\
$\mathrm{~T}_{8}$ & 26690 \\
$\mathrm{~T}_{9}$ & 2036 \\
\hline
\end{tabular}

In what fallows, without loss of generality of the problem, the approximated values balance sheet for current years is predicted for less calculation based on the previous information and bank policies.

\begin{tabular}{cl} 
TABLE III: PREDETERMINED VALUES FOR SOME VARIABLES \\
\hline \hline variable & Predicted value \\
\hline $\mathrm{C}_{1}$ & 4798418 \\
$\mathrm{C}_{2}$ & 5249370 \\
$\mathrm{~S}_{1}$ & 1695635 \\
$\mathrm{~S}_{2}$ & 9370 \\
$\mathrm{~S}_{3}$ & 2324 \\
$\mathrm{~S}_{4}$ & -31766 \\
$\mathrm{~T}_{1}$ & 170436 \\
$\mathrm{~T}_{2}$ & 56542 \\
$\mathrm{~T}_{3}$ & -68824 \\
$\mathrm{~T}_{4}$ & -151280 \\
$\mathrm{~T}_{5}$ & -150968 \\
$\mathrm{~T}_{6}$ & -72350 \\
$\mathrm{~T}_{7}$ & -47828 \\
$\mathrm{~T}_{8}$ & -3310 \\
$\mathrm{~T}_{9}$ & -1306 \\
\hline \hline
\end{tabular}

Besides above issues, some cases such as moderations result from currency rate alignment and asset and liability which doesn't have dynamicity like other assets would be bounded. Some elements are considered from industry as:

$$
\begin{array}{lll}
\mathrm{A}^{\mathrm{N}}=24476761 & & \mathrm{~L}^{\mathrm{N}}=22781126 \\
\gamma=1 / 2 & \mathrm{~N}=4 & \mathrm{Z}=78000 \\
\mathrm{r}_{1}=0.1 & \mathrm{r}_{2}=0 & \mathrm{r}_{3}=0.03 \\
\mathrm{r}_{4}=0.01 & \mathrm{r}_{5}=0.05 & \mathrm{r}_{6}=0.02 \\
\mathrm{r}^{\prime}{ }_{1}=0.03 & \mathrm{r}_{2}=0.014 & \mathrm{E}\left[\mathrm{G}^{\prime}{ }_{1}\right]=0.68 \\
\mathrm{E}\left[\mathrm{G}_{2}{ }_{2}\right]=12.15 & \mathrm{E}^{2}\left[\mathrm{G}^{\prime}{ }_{3}\right]=0.099 \\
\multicolumn{2}{c}{\mathrm{E}\left[\mathrm{G}^{\prime}{ }_{4}\right]=0.07} & \text { inflation }=\% 7
\end{array}
$$

Now, using the research model, above information and LINGO, an optimal state would be obtained for asset and liability portfolio and we have:

TABLE IV: OPTIMAL ASSETS AND LIABILITY

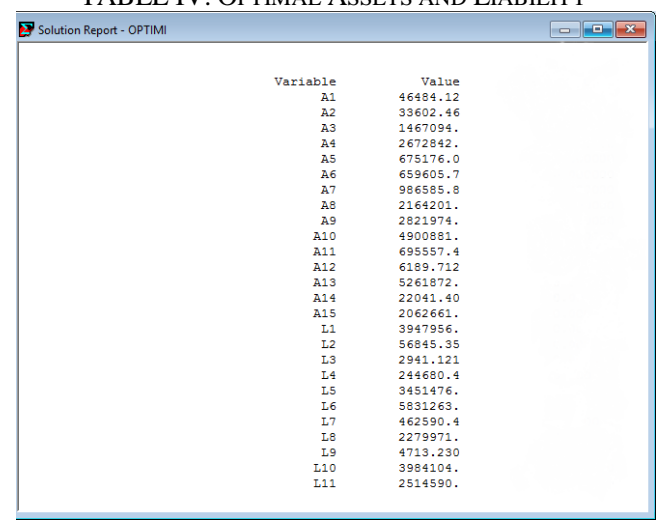

What occurred for the hypothesized bank is as follow:

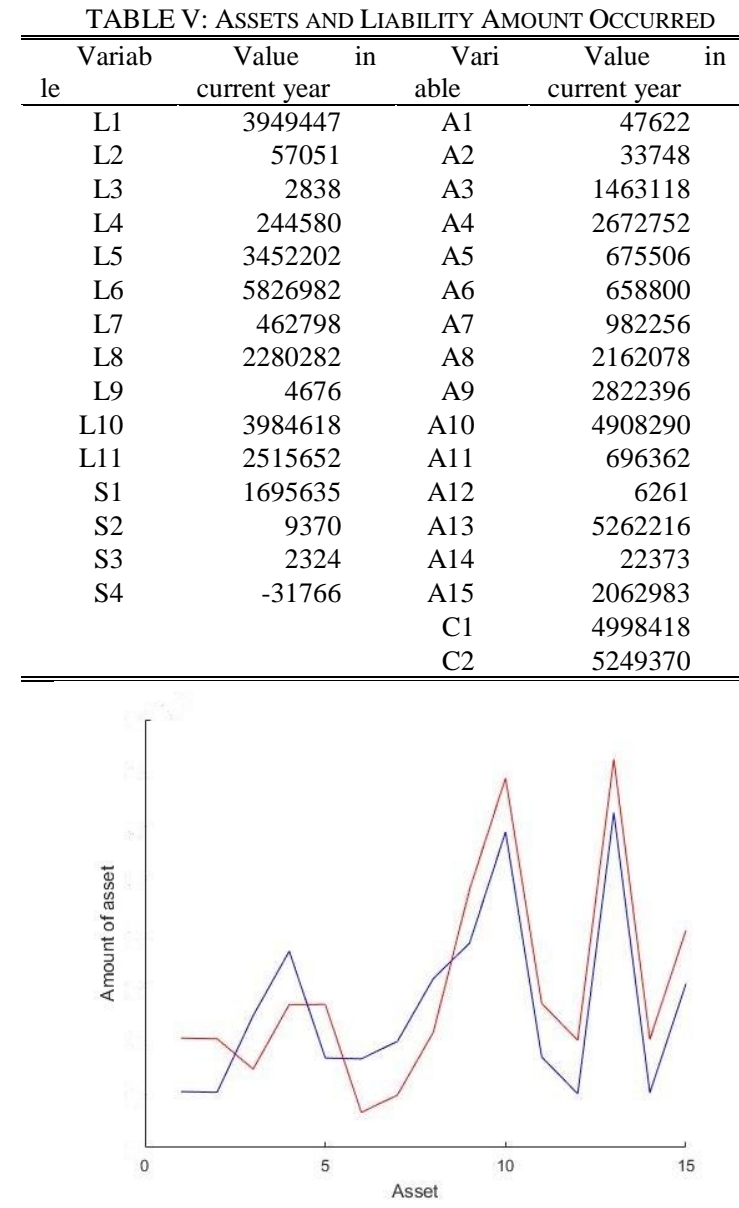

Fig. 1. Asset amount in optimal and occurred situations.

The difference between optimal and occurs situations is principally natural. Generally, bank has to try to achieve the optimal situation. The result diagrams are indicates in 
following section. In diagrams generally the red line is the assets and liability amount occurred and blue line is the asset and liability in optimal situation. The horizontal axis is the asset and liability considered and the vertical one is the amount. The asset changes relative to previous year is as follow:

As it is seen from diagram, it is evident that in current year the assets in low-productive sectors has been assigned the highest level of the capital, particularly the facilities given which are very important.

The liability diagram is demonstrated as:

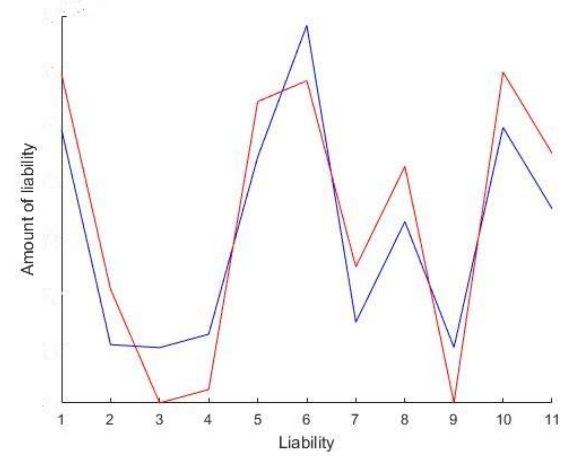

Fig. 2. Comparison between liability in optimal and occurs situations.

It is evident from above diagram that the short-term fundraising in bank has been increasing and bank has to try to make its customers satisfied regarding the long-term deposits.

\section{CONCLUSION}

In this research, we attempted to optimize the bank's asset and liability portfolio which is involved in different positions. Our optimization is under the condition of respecting the financial ratio in banks which was solved using modeling the Goal fractional optimization and changing it to a linear model. This approach, in turn, is a new and highly efficient and simple approach. This approach in optimizing the asset and liability portfolio of the bank can be used for different banks. Among the features of this model are dynamicity of the programing and increasing the ratios in line with each other or other limitations. Using this optimization, bank can make correct policies for its financial future and compensate for its deficiencies and approach the optimal situation. The assets with higher risks can be used in asset and liability structure for banks and it is possible to make use of the randomized interest rated in this model.

\section{REFERENCES}

[1] I. M. Kusy and T. W. Ziemba, "A bank asset and liability management model," Operations Research, vol. 34, no. 3, pp. 365-375 , 1986.

[2] Basle Committee on Banking Supervision, "International Covergagence of capital Measurment and Capital Standards: Revised Framework," Comprehensive Version, Bank for International Settelment, Basel, June, 2006.

[3] L. Novickyte and I. Petraityte, "Assessment of banks asset and liability management: Problems and perspectives (case of Lithuania)," Procedia - Social and Behavioral Sciences 1101082 - 1093, 2014.

[4] M. P. Zandi, "Designing a model in order to predict and optimize the asset and liability in banking system," I.A.U of Tehran, Science and research unit, Department of economy and management, 2013.
[5] M. Pour Zandi and M. Gholamreza, "Designing and codifying evaluation pattern for effect of asset and liability management application in banks using Goal programing model," Applied Mathematics Journal, 2006.

[6] M. Moghadam "Assets and liabilities management and its role in codifying the integrated asset-liability decision making optimal strategies," Ayandeh Bank Publication, 2013.

[7] A. Scholtz, "The spread spectrum concept," Multiple Access, N. Abramson, Ed. Piscataway, NJ: IEEE Press, 1993, ch. 3, pp. 121-123.

[8] Risk evaluation and management group of Eghtesad Novin Bank, measurement and management of the operational risk in financial institutes, Farasokhan Publication, 2008.

[9] L. Mehrabi, "Asset and liability management in Islamic banks," Central bank's Monetary and Banking Research Center, 2013.

[10] N. Naghshine and F. Hanifi, and H. K. Luie, "Bank's asset and liability manage, ent using multipurpose linear programing and simulation of the econometrics, case study: Bank X," Journal of Financial Engineering and Portfolio Management, 2013.

[11] M. Choudhry and I. Henry, "Bank asset and liability management: Strategy, trading, analysis," Wiley, 2007.

[12] J. Pan and Q. Xiao, "Optimal asset-liability management with liquidity constraints and stochastic interest rates in the expected utility framework," Journal of Computational and Applied Mathematics,2008.

[13] L. C. MacLean, Y. Zhao, and W.T. Ziemba, "Intertemporal mean variance efficiency with Markovian state price density," Journal of Banking and Finance, Motorola Semiconductor Data Manual, Motorola Semiconductor Products Inc., Phoenix, 2011.

[14] A. Vafadar, "Financial ratios and analysis of the banks financial statements," Humanities and Cultural Studies Research Center, 2015.

[15] C. T. Chang, "Multi_choice goal programming," Omega, vol. 35, no. 4, pp. 389-396, 2007.

[16] F. Chen and G. H. Huang, Y. R. Fan, and R. F. Liao, "A nonlinear fractional programming approach for environmental-economic power dispatch," Electrical Power and Energy Systems, vol. 78, pp. 463-469, 2016.

[17] I. Lachhwani and K. Modified, "FGP approach for multilevel multiobjective linear fractional programming problems," Applied Mathematics and Computation, 2015.

[18] J. Razmi, E. Jafarian, and S. Hassanzadeh, "An intuitionistic fuzzy goal programming approach for finding pareto-optimal solutions to multi-objective programming problems," Expert Systems with Applications, 2016.

[19] M. Rudolf and W. T. Ziemba, "Intertemporal Asset-Liability Management," Journal of Economic Dynamics and Control, pp. 975-990, 2004.

[20] R. D. Young and C. Yom, "On the independence of assets and liabilities: Evidence from U.S. commercial banks, 1990-2005," Journal of Financial Stability, 2008.

[21] S. A. Zenios and W.T. Ziemba, "Handbook at asset and liability management," vol. 1, Teort and Methodology, North- Holand, 2006.

[22] W. T. Ziemba, "Asset-liability management," Handbook of Quantitative Finance, 2010.

[23] W. T. Ziemba and J. M. Mulvey, Asset and Liability Management from a Global Perspective, Cambridge University Press, 2003.

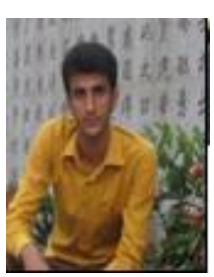

Seyed Mohammad Esmaeil Pourmohammad Azizi is the graduate student in financial mathematics at Department of Mathematics, Allameh Tabatabae'i university (ATU), Tehran, Iran. He received his B.Sc. in mathematic (2015). He has achieved 2nd in tournament at international conference in OR, Semnan, Iran (2014). His research interest is modelling in finance, invers problems in finance, operation research, economic and finance.

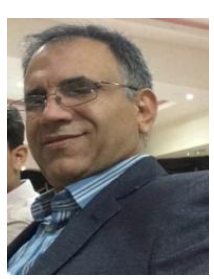

Abdolsadeh Neisy is associate professor in mathematics at Department of Mathematics, Allameh Tabatabae'i university (ATU), Tehran, Iran. He has obtained his $\mathrm{PhD}$ degree in Iran University of Science and Technology. He published 100 paper in Numerical Analysis and Finance. He also guided more than 90 post graduate theses. His research interest is financial mathematics, financial derivatives, stoke model and oil future model. 